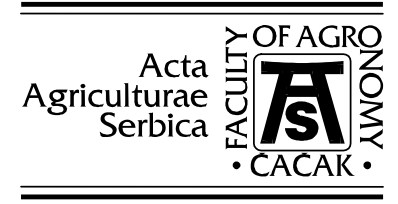

\title{
Effect of cereals + pea intercropping on spike index of spring wheat, triticale, oat and pods index of pea
}

\author{
Milosav Grčak ${ }^{1}$, Dragan Grčak ${ }^{1}$, Vesna Župunski ${ }^{2}$, Radivoje Jevtić ${ }^{2}$, \\ Mirjana Lalošević ${ }^{2}$, Adriana Radosavac ${ }^{3}$, Danijela Kondić ${ }^{4}$, Jelica Živić ${ }^{5}$, \\ Aleksandar Paunović ${ }^{6}$, Veselinka Zećević ${ }^{7}$, Danica Mićanović ${ }^{8}$, \\ Desimir Knežević ${ }^{1}$ \\ ${ }^{1}$ University of Priština, Faculty of Agriculture, Kosovska Mitrovica - Lešak, \\ Kopaonička bb, 38219 Lešak, Kosovo and Metohia, Serbia, \\ ${ }^{2}$ Institute of Field and Vegetable Crops, Maksima Gorkog 30, 21000 Novi Sad, Serbia \\ ${ }^{3}$ University Business Academy in Novi Sad, Faculty of Applied Management, Economics \\ and Finance in Belgrade, Jevrejska 24, 11000 Belgrade, Serbia \\ ${ }^{4}$ University of Banja Luka, Faculty of Agriculture Banjaluka, Aveue Vojvode Petra \\ Bojovića, 1A, 78000 Banjaluka, Republika Srpska, Bosnia \& Herzegovina \\ ${ }^{5}$ College of Agriculture and Food Technology, Prokuplje, Serbia \\ ${ }^{6}$ University of Kragujevac, Faculty of Agriculture, Cara Dušana 34, Čačak 32000, \\ Serbia \\ ${ }^{7}$ University Megatrend, Belgrade, Faculty of Biopharming Backa Topola, Serbia; \\ ${ }^{8}$ Serbian Chamber of Commerce and Industry, Resavska15, Belgrade, Serbia \\ Corresponding author: deskoa@ptt.rs
}

\begin{abstract}
Advantages or disadvantages of intercropping system can estimate through expression of components of yield on the base of values of productive organs (spike, pod). The aim of this work was study of variation of spike index in cereals species and pods index in pea of spring intercropping. For investigation included spring species of small grains: wheat, triticale, oat and spring legume pea. The investigation was carried out in field condition in experiment with randomised block design of $5 \mathrm{~m}^{2}$ plots, with 4 replications. Each species (cereals and pea) were sown sole and in intercrops wheat+pea, triticale+pea and oat+pea. At the maturity stage used 40
\end{abstract}

Received 10 November 2019 Accepted 12 December 2019 
plants (10 plants/replication) for determining harvest index of spike in cereal species and index of pea pods on the base of analysis of spike mass and pod mass and seed mass spike ${ }^{-1}$ and seed mass $\operatorname{pod}^{-1}$. Seed mass spike ${ }^{-1}$ of small grains species genotypes variate in ratio of $0.85 \mathrm{~g}$ (wheat+pea) and $1.59 \mathrm{~g}$ (oat intercrops) with average $1.19 \mathrm{~g}$ for all crops of cereals and variant of cultivation. The spike mass variate in range of $1.37 \mathrm{~g}$ (triticale intercrop) and $2.23 \mathrm{~g}$ (wheat intercrops) with average $1.72 \mathrm{~g}$ for all cereals and variant of cultivation. Harvest index of spike variate between $62.5 \%$ (triticale sole) and $89.2 \%$ (oat sole). The value of spike mass was the higher in wheat intercrops than in wheat sole, while for triticale and oat spike mass is lower in intercrops. In the same of analyzed small grain species, seed mass was the higher in sole crops than in mixture with pea. The spike index, only in intercrop triticale+pea $(63.2 \%)$ was slightly higher than in single crop of triticale $(62.5 \%)$. Pod mass and seed mass pod $^{-1}$ of pea was the higher in pea intercrops than in pea sole. The highest pod mass was in intercrop pea+triticale $(0.72 \mathrm{~g})$ and the least in single crop of pea $(0.45 \mathrm{~g})$ with average $0.62 \mathrm{~g}$ for all crops. The highest seed mass pod $^{-1}$ was the highest intercrop pea+triticale $(0.56 \mathrm{~g})$ and the least in monocrop of pea $(0.32 \mathrm{~g})$ with average $0.46 \mathrm{~g}$ for all crops. Harvest index of pod variate in ratio $68.0 \%$ (pea single) and $77 . \%$ in pea/triticale intercrop. Pod index of pea in mixture with each small grains species genotypes was higher than in pea's monocrop. On the base of result we can conclude that intercropping cereals + pea, have positive effect on spike and pod characteristics which values were higher in majority of studied intercrops than in monocrops.

Keywords: spike index, pod index, intercrops, cereals, pea.

\section{Introduction}

In production practice of cereal and other annual crops are sown as monocultures with applied crop rotation to protect soil properties (fertility of soil, nutrients) and suppressing weeds, reduce pest and pathogens (Smith et al., 2011). The achievement of high yield in conventional cultivation determined with genetic control of numerous traits of seed (Knežević et al., 2019a), stem (Branković et al., 2015) nitrogen nutrition (Knežević et al., 2016; Stupar et al., 2017) soil quality and regime of fertilization (Madić et al., 2019) agro ecological conditions (Kondić et al., 2012). The monocrop of pea and cereals characterize good productivity. However, the tendency of pea lodging is the main reason of recommending intercropping system of pea with cereals (Lauk and Lauk, 2008).

Production of forage in system of growing cereal-legume intercrops in recent time widely accepted from the reason of efficient utilization of arable land areas, improving soil fertility, increasing biodiversity, improving quality of crops, reducing weeds and pests (Gill and Omokanye, 2018; Golijan and Marković, 2018). Intercropping system contribute to increasing of yield increasing yields (Mikić et al., 2012; Aziz et al., 2015), reducing lodging (Sabolović, 2014), reducing weeds (Simić et al., 2018) and reducing diseases (Markovic, 2013; Živanov, 2014). Plant interaction in intercropping system contribute to improving of soil quality, increasing cycling of nutrient, conservation of soil moisture and crop production (Chu et al., 2017; Davis et al., 2015; Smith et al., 2014). Crop species in mixture contribute to increase biodiversity in soil and in field 
crops (agroecosystem) and can express different time of developing stage to the maturity time (BCRC, 2016; Veličković et al., 2016).

This study evaluated the crop yield and soil properties from growing a multispecies cover crop mixture compared with those from the less-diverse single- and doublespecies cover crops and no-cover control in a corn-soybean production system in west Tennessee. After 3 years of establishing a multispecies cover crop mixture, we found increased soybean yield in comparison with less-diverse cover crops and a no-cover control. We also found increased soil inorganic $\mathrm{N}$ and soil moisture content from plots planted with double- and multispecies cover crops compared with plots with singlespecies and no-cover crops. Soil organic $\mathrm{C}$ content was unaffected by the cover crop treatments and duration of cover cropping (Chu et al., 2017)

Intercropping with wheat is a practical alternative to enhance ground cover at establishing forage legumes. At least of $62 \%$ ground cover can be expected eight weeks after sowing. The grain yield in wheat intercrop with forage legumes is stable (Tomm and Foster, 2001). The investigation of triticale in intercropping with forage crops showed positive effect to grain quality (Lestingi et al., 2010; Nefir and Tabără, 2011). The productivity of spring cereal monocrops and pea/cereal intercrops studied and found that grain yield variate in dependence of genotype of cereal and environmental condition (Kadžiulienè et al., 2011). They found that in some environmental condition grain yield was higher in intercrops and that in pea/cereal intercrop expressed stable yield.

In monocrops of wheat the spike index (Dimitrijevic et al., 2006) grain weight spike $^{-1}$ (Knežević et al., 2015) weight of spike (Knežević et al., 2019b) variate in dependence of genotype and environmental factor. In other study the spike index varied between 0.60 to 0.83 (Petrović et al., 2002)

The aim of this investigation was to identify the variability of the spike index for wheat, triticale, oats and variation of pea pods index, based on the values of weight of seeds, the weight of the spikes and the weight of the pods in the monocrops and intercrops cultivation.

\section{Materials and methods}

The spring small grain species: wheat, triticale, oat and spring pea were used for experimental investigation of harvest spike index, pod index and weight of spike and pod and weight of seed spike ${ }^{-1}$ and seed $\operatorname{pod}^{-1}$. Experiment carried out in 2018 at an experimental field of the Institute of Field and Vegetable Crops in Novi Sad $\left(45^{\circ} 33^{\prime} \mathrm{N}\right.$, $\left.19^{\circ} 84^{\prime} \mathrm{E}\right)$. Design of experiment was randomized block system on plots size $5 \mathrm{~m}^{2}$ in 4 repetitions, included monocrops of wheat (Triticum aestivum), triticale (Triticosecale), oats (Avena sativa) and pea and intercrops pea/wheat, pea/triticale and pea/oats. Monitored varieties were: wheat - Nataša, triticale - Odisej, Oats - Dunav, pea - Junior. The sowing density per $\mathrm{m}^{2}$ for monocrop of small grains was as follows: wheat 600 grains, triticale 500 grains and oats 500 grains, whereas the sowing norm for the pea in 
independent crops was 100 grains per $\mathrm{m}^{2}$. In the mixture, the sowing density per $\mathrm{m}^{2}$ was 70 grains of pea +180 grains of wheat, 150 grains of triticale and 150 grains of oat.

Samples of plants for analysis were taken using the test method with $0.25 \mathrm{~m}^{2}$ frame, in three developing phase of plant (first in June 4, 2018 at the flowering phase, second in June 14 at the early milky phase and third in June 26 at the early waxy phase) from both monocrops and intercrops. The plants were dried in a glasshouse. For each crops of genotypes were used 40 plants (10 plants per four repetitions) for analysis of mass of spike, mass of seed spike ${ }^{-1}$, mass of seed $\operatorname{pod}^{-1}$ and mass of pea pod. Based on the obtained average values of the mass of the seed and spike, the spike index is computed by using the formula:

$$
\text { Spike index }(\%)=\frac{\text { mass of seeds }}{\text { mass of spike }} \times 100
$$

On the basis of the obtained average values of the mass of the pod and seeds, the pod index of pea was computed by using the formula:

$$
\text { Pod index }(\%)=\frac{\text { mass of seeds }}{\text { mass of pod }} \times 100
$$

Statistical data processing was done using the MSTAT C 5.0 version. An analysis of variance was conducted for mono-factorial system and the significance of the differences was tested by using the LSD test (Hadživuković, 1991).

Euclidian distance and similarity among small on the base of values ear harvest index traits obtained in monocrops and intercrops with pea, and distance and similarity of pea pod index value obtained in monocrops and mixture pea + small grain species (wheat, triticale, rye and oat) analyzed by using IBM SPSS Statistics 20.

\section{Results and discussion}

The spike weight varied in the range from $1.23 \mathrm{~g}$ in wheat/pea intercrop to $2.0 \mathrm{~g}$ in oat monocrop. The weight of spike of oat monocrop $(2.0 \mathrm{~g})$ was significantly higher than in triticale intercrop (1.37 g) than in wheat intercrop (1.23 g), than in wheat monocrop (1.41 g). Also, spike weight of oat monocrop (2.0 g) was higher than in triticale monocrop $(1.52 \mathrm{~g})$ and then in oat/pea intercrops $(1.81 \mathrm{~g})$, but not significantly. The spike weight of oat/pea intercrop $(1.81 \mathrm{~g})$ was significantly higher than in wheatpea intercrop (1.52 g) and higher but not significant than in triticale/pea intercrop (1.37 g) than in triticale monocrop $(1.52 \mathrm{~g})$ and than in wheat monocrop $(1.41 \mathrm{~g})$ Table 1 and 2.

It can be noted that the spike weight in monocrops of spring wheat, triticale and oat was higher than in the same small grain species grown in the mixture with pea.

The similar ratio of variability of spike weight was found in monocrops of wheat (Dimitrijević et al., 2006; Knežević et al., 2019b).

The seed weight variate from the least value in wheat/pea intercrop $(0.87 \mathrm{~g})$ to the highest in oat monocrop $(1.79 \mathrm{~g})$. For each small grain species values of seed mass 
spike $^{-1}$ was higher than in same cereal species grown in mixture with pea. The seed weight in oats grown as monocrop $(1.79 \mathrm{~g})$ was slightly higher than in the mixture with pea $(1.59 \mathrm{~g})$ and significantly higher than weight of seed spike ${ }^{-1}$ in wheat monocrop $(1.02 \mathrm{~g})$, triticale monocrop $(0.99 \mathrm{~g})$, wheat/pea intercrop $(0.87 \mathrm{~g})$ and triticale/pea intercrop ( $0.89 \mathrm{~g})$. In wheat monocrop $(1.01 \mathrm{~g})$, triticale monocrop $(0.99 \mathrm{~g})$, wheat/pea $(085 \mathrm{~g})$ and triticale/pea intercrop $(0.89 \mathrm{~g})$ value of seed weight were different but not significantly different (Table 1 and 3).

In study of Kadžiuliene et al. (2011) found that grain yield was higher in intercrops depends of environmental condition, and that grain yield was stable in intercrops pea/cereal. The stable grain yield in wheat intercrop with forage legumes is stable (Tomm and Foster, 2001).

The harvest index of spike varied from $65.2 \%$ in triticale grown in the mixture with pea to $89.2 \%$ in monocrop of oats (Table 1). The harvest index of spike in oats monocrop $(89.2 \%)$ and in intercropping of oats with pea $(88.1 \%)$ was significantly higher than in wheat monocrop $(71.9 \%)$ and triticale monocrop $(65.3 \%)$, and also was higher than in the mixtures of wheat+pea $(70.8 \%)$ and than in triticale+pea intecrop $(65.2 \%)$. The spike index in wheat monocrop $(71.9 \%)$ was higher than in wheat/pea intercrop (70.8\%) and spike index in triticale sole crop (65.3\%) was similar to harvest index of spike in triticale/pea intercrop (65.2\%) (Table 1 and 4).

Table 1. The spike traits of small grains spring species in monocrops and in mixture with pea

\begin{tabular}{|l|c|c|c|}
\hline & Spike mass $(\mathrm{g})$ & Seed mass spike $^{-1}(\mathrm{~g})$ & H index of spike (\%) \\
\hline Wheat & $1,409 \mathrm{bc}$ & $1,015 \mathrm{~b}$ & $0,719 \mathrm{~b}$ \\
\hline Triticale & $1,521 \mathrm{abc}$ & $0,993 \mathrm{~b}$ & $0,653 \mathrm{~cd}$ \\
\hline Oat & $2,004 \mathrm{a}$ & $1,788 \mathrm{a}$ & $0,892 \mathrm{a}$ \\
\hline Wheat/pea & $1,227 \mathrm{c}$ & $0,869 \mathrm{~b}$ & $0,708 \mathrm{bc}$ \\
\hline Triticale/pea & $1,373 \mathrm{bc}$ & $0,896 \mathrm{~b}$ & $0,652 \mathrm{bc}$ \\
\hline Oat/pea & $1,809 \mathrm{ab}$ & $1,594 \mathrm{a}$ & $0,881 \mathrm{a}$ \\
\hline Average & $\mathbf{1 . 7 2 4}$ & $\mathbf{1 . 1 9 2}$ & $\mathbf{0 . 7 5 1}$ \\
\hline
\end{tabular}

Values within columns with different superscripts are significantly different $(\mathrm{p} \leq 0.05)$

Table 2. ANOVA for spike mass of cereals spring species in monocrops and in mixture with pea

\begin{tabular}{|l|c|c|c|c|c|c|c|}
\hline \multirow{2}{*}{ Source of variation } & \multirow{2}{*}{ DF } & \multirow{2}{*}{ SS } & \multirow{2}{*}{ MS } & \multirow{2}{*}{ F } & \multirow{2}{*}{ Prob } & \multicolumn{2}{c|}{ LSD } \\
\cline { 6 - 9 } & & & & & & 0.05 & 0.01 \\
\hline Replication & 3 & 0.036 & 0.012 & 0.148 & - & - & - \\
\hline Monocrop and intercrops species & 5 & 0.718 & 0.344 & $4.248^{*}$ & 0.0132 & 0.5173 & 0.8115 \\
\hline Error & 15 & 1.213 & 0.081 & - & - & - & - \\
\hline Total & 23 & 2.967 & - & - & - & - & - \\
\hline
\end{tabular}


Table 3. ANOVA for seed mass of spring small grains species in monocrop and intercrops with pea

\begin{tabular}{|l|c|c|c|c|c|c|c|}
\hline \multirow{2}{*}{ Source of variation } & \multirow{2}{*}{ DF } & \multirow{2}{*}{ SS } & \multirow{2}{*}{ MS } & \multirow{2}{*}{ F } & \multirow{2}{*}{ Prob } & \multicolumn{2}{c|}{ LSD } \\
\cline { 7 - 9 } & & & & & & 0.05 & 0.01 \\
\hline Replication & 3 & 0.021 & 0.007 & 0.1148 & - & - & - \\
\hline Monocrop and intercrops species & 5 & 3.116 & 0.623 & $10.2556^{* *}$ & 0.0002 & 0.4489 & 0.7042 \\
\hline Error & 15 & 0.912 & 0.061 & - & - & - & - \\
\hline Total & 23 & 4.049 & - & - & - & - & - \\
\hline
\end{tabular}

Table 4. ANOVA for harvest index of spring small grains species in monocrop and in mixture with pea

\begin{tabular}{|l|c|c|c|c|c|c|c|}
\hline \multirow{2}{*}{ Source of variation } & \multirow{2}{*}{ DF } & \multirow{2}{*}{ SS } & \multirow{2}{*}{ MS } & \multirow{2}{*}{ F } & \multirow{2}{*}{ Prob } & \multicolumn{2}{c|}{ LSD } \\
\cline { 7 - 9 } & & & & & & 0.05 & 0.01 \\
\hline Replication & 3 & 0.009 & 0.003 & $2.5372^{\text {ns }}$ & 0.0958 & - & - \\
\hline Monocrop and intercrops species & 5 & 0.237 & 0.047 & $40.8267^{* *}$ & 0.0000 & 0.0575 & 0.0902 \\
\hline Error & 15 & 0.017 & 0.001 & - & - & - & - \\
\hline Total & 23 & 0.263 & - & - & - & - & - \\
\hline
\end{tabular}

The analysis of variance of the pod weight in pea show that the highest value of the pod weight $(0.72 \mathrm{~g})$ was in the intercrops of pea and triticale and the lowest pod weight in pea $(0.45 \mathrm{~g})$ grown as monocrop. The pod mass in pea/wheat $(0.64 \mathrm{~g})$ was slightly higher than in pea/oat intercrop $(0.58 \mathrm{~g})$. Differences of pod mass in pea obtained in all analyzed variant of crop system are not significant (Table 5 and 6).

The seed mass pod $^{-1}$ varied from $0.33 \mathrm{~g}$ in pea monocrop to $0.57 \mathrm{~g}$ in pea/triticale intercrop. The value of seed mass pod $^{-1}$ in pea/wheat intercrop $(0.49 \mathrm{~g})$ was the higher than in pea/oat $(0.46 \mathrm{~g})$. The seed mass $\operatorname{pod}^{-1}$ in all analyzed intercrops was higher than in pea monocrop, but obtained values of seed mass $\operatorname{pod}^{-1}$ in all variant of crops (monocrop and intercrop) were not significant (Table 5 and 7).

In study of cereals-legume intercrops the grain yields was significantly higher in intercrops than in monocrop (Hauggaard-Nielsen et al., 2008). The investigation of triticale in intercropping with forage crops showed positive effect to grain yield and quality (Lestingi et al., 2010; Nefir and Tabără, 2011).

The pod index in pea grown as monocrop $(72.9 \%)$ was lower than in pea grow in the mixture with other crops: pea/wheat $(77.30 \%)$, pea/triticale $(78.6 \%)$ and pea/oat (79.4\%). The obtained values for pod index in pea monocrops and pea intercrops with wheat, triticale and oat, were not significant different (Table 5 and 8). 
Table 5. Pod characteristics of pea in sole crops and intercrops pea/small grains of spring species varieties

\begin{tabular}{|l|c|c|c|}
\hline & Pod mass $(\mathrm{g})$ & Seed mass pod $^{-1}(\mathrm{~g})$ & H index $(\%)$ \\
\hline Pea & 0.4523 & 0.3305 & 0.7290 \\
\hline Pea/Wheat & 0.6430 & 0.4992 & 0.7730 \\
\hline Pea/Triticale & 0.7237 & 0.5705 & 0.7862 \\
\hline Pea/Oat & 0.5780 & 0.4618 & 0.7940 \\
\hline Average & $\mathbf{0 . 5 9 9 2}$ & $\mathbf{0 . 4 6 5 5}$ & $\mathbf{0 . 7 7 0 6}$ \\
\hline
\end{tabular}

Table 6. ANOVA for pod mass of pea in sole crops and intercrops with small grains spring of species varieties

\begin{tabular}{|l|c|c|c|c|c|c|c|}
\hline \multirow{2}{*}{ Source of variation } & \multirow{2}{*}{ DF } & \multirow{2}{*}{ SS } & \multirow{2}{*}{ MS } & \multirow{2}{*}{ F } & \multirow{2}{*}{ Prob } & \multicolumn{2}{c|}{ LSD } \\
\cline { 6 - 9 } & & & & & & 0.05 & 0.01 \\
\hline Replication & 3 & 0.026 & 0.009 & $0.4637^{\text {ns }}$ & - & - & - \\
\hline Monocrop and intercrops species & 3 & 0.158 & 0.053 & $2.7688^{\text {ns }}$ & 0.1032 & 0.3102 & 0.5693 \\
\hline Error & 9 & 0.171 & 0.019 & - & - & - & - \\
\hline Total & 15 & 0.355 & - & - & - & - & - \\
\hline
\end{tabular}

Table 7. ANOVA for seed mass of pod of pea in sole crops and intercrops with small grains of spring species varieties

\begin{tabular}{|l|c|c|c|c|c|c|c|}
\hline \multirow{2}{*}{ Source of variation } & \multirow{2}{*}{ DF } & \multirow{2}{*}{ SS } & \multirow{2}{*}{ MS } & \multirow{2}{*}{ F } & \multirow{2}{*}{ Prob } & \multicolumn{2}{c|}{ LSD } \\
\cline { 7 - 9 } & & & & & & 0.05 & 0.01 \\
\hline Replication & 3 & 0.024 & 0.008 & $0.5628^{\mathrm{ns}}$ & - & - & - \\
\hline Monocrop and intercrops species & 3 & 0.122 & 0.041 & $2.8897^{\mathrm{ns}}$ & 0.0947 & 0.2663 & 0.4887 \\
\hline Error & 9 & 0.126 & 0.014 & - & - & - & - \\
\hline Total & 15 & 0.272 & - & - & - & - & - \\
\hline
\end{tabular}

Table 8. ANOVA for $\mathrm{H}$ index $\mathrm{H}$ index of pod of pea in sole crops and intercrops with small grains of spring species varieties

\begin{tabular}{|l|c|c|c|c|c|c|c|}
\hline \multirow{2}{*}{ Source of variation } & \multirow{2}{*}{ DF } & \multirow{2}{*}{ SS } & \multirow{2}{*}{ MS } & \multirow{2}{*}{ F } & \multirow{2}{*}{ Prob } & \multicolumn{2}{c|}{ LSD } \\
\cline { 7 - 9 } & & & & & & 0.05 & 0.01 \\
\hline Replication & 3 & 0.005 & 0.002 & $2.8622^{\mathrm{n}}$ & 0.0966 & - & - \\
\hline Monocrop and intercrops species & 3 & 0.010 & 0.003 & $6.4114^{*}$ & 0.0130 & 0.0712 & 0.1306 \\
\hline Error & 9 & 0.005 & 0.001 & - & - & - & - \\
\hline Total & 15 & 0.019 & - & - & - & - & - \\
\hline
\end{tabular}

The analysis of variance of the pod weight in pea showed that the lowest pod weight was achieved in the mixture of pea + oat. The obtained value of pod weight in pea 
monocrop was lower but not significantly lower than pod weight in pea grown in mixture with wheat, triticale and oat (Table 5).

The obtained average values of seed mass $\operatorname{pod}^{-1}$ in pea were not significantly different from seed mass pod $^{-1}$ in pea grown in intercrop with wheat, triticale and oat (Table 7).

Also, the pod index in monocrop of pea was not significantly different in relation to pod index of pea grown in the mixture with other crops (wheat, triticale and oat). The values of pod index in pea grown in the mixture with wheat, triticale and oat were not significantly different (Table 9).

In this investigation of spring small grains species grown as monocrop or as mixture of wheat/pea, triticale/pea, oat/pea were compared to each other on the base of value of harvest spike index.

The similarity with Euclidean distance was made and presented in dendogram (Figure 1). Among those six crops expressed different degree of distance or similarity. The least distance of 1.0 units or the highest similarity was estimated in three pair of the same species grown as monocrops and as intercrops with pea. In fact, the minimum distance exists in the one pair between wheat monocrop and wheat/pea intercrop, in the second pair between triticale monocrop and triticale/pea intercrop and in the third pair between oat monocrop and oat/pea intercrop. Between first pair (triticale and triticale/pea) and second pair of crops (wheat and wheat/pea) expressed the distance of the 4.0 units in the range of 25 units. The highest distance of 25 units expressed between cluster of two pairs (triticale, triticale/pea and wheat, wheat/pea) and third pair (oat and oat/pea) in the range of 25 units.

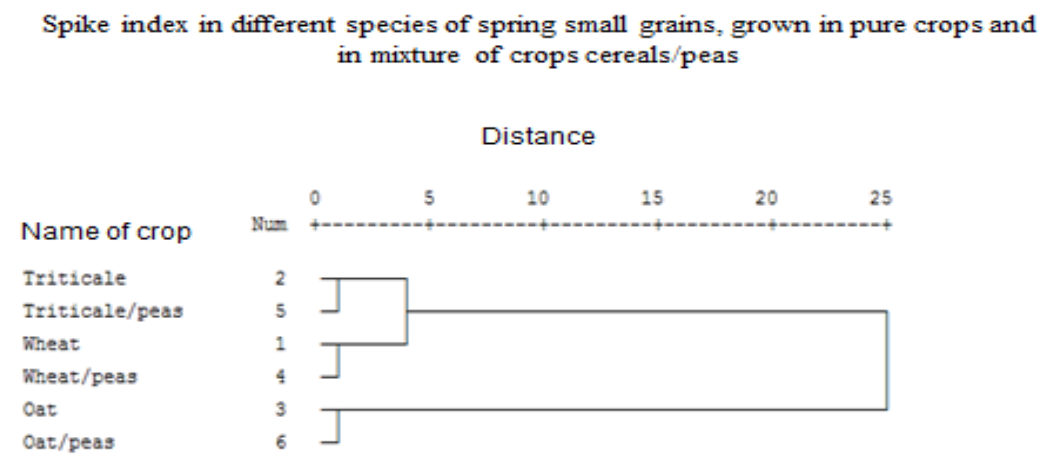

Figure 1. Dendogram for distance among spring cereal species according to value of spike index obtained in single crops system and intercropping system of growing 
According to obtained value of pod index of spring pea, grown as monocrop or mixture of pea/small grain species, were compared to each other, by using hierarchical methods of Euclidean distance. The clustering presented on dendogram. Among those four crops were expressed different level of distance or similarity on the base of value of pod index. The least distance of 1.0 unit in the range of 25 units, was expressed between pea monocrop and pea/oat intercrop. The intercrop pea/wheat associated to pair pea and pea/oat on the distance of 3.0 units in the range of 25.0 units. The remain intercrop pea/triticale joins to previous formed cluster (pea, pea/oat and pea/wheat) on the distance of 25 units in the range of 25.0 units (Figure 2).
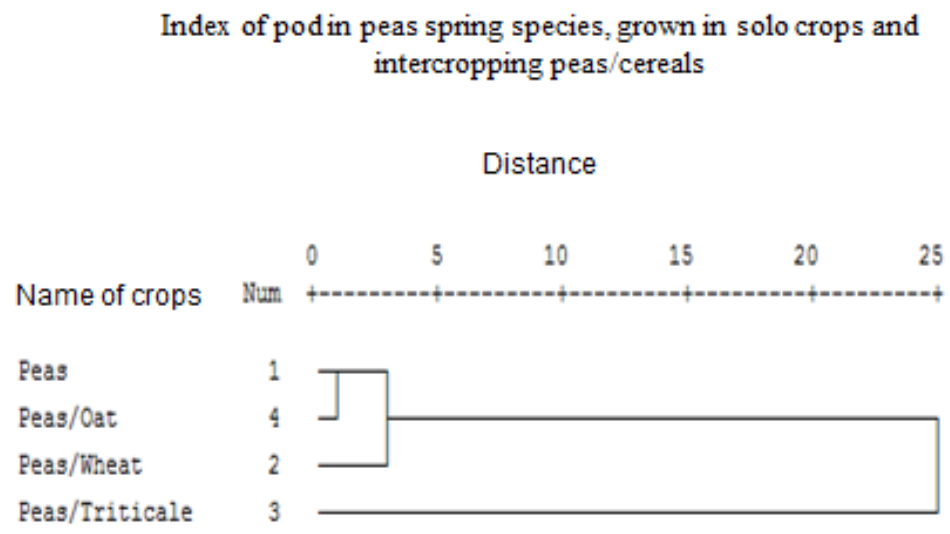

Figure 2. Dendogram for distance among spring pea according to value of pod index obtained in single crop and in intercropping system pea/small grains species

\section{Conclusion}

In this study were found different values of spike mass, seed mass spike ${ }^{-1}$ in small grain species (wheat, triticale, oat), different pod mass and seed mass $\operatorname{pod}^{-1}$ in pea, depends of crop system. The values of weight of spike and seed mass spike $^{-1}$ in the same spring cereal species were higher in monocrops than in intercrops. However weight of pod and seed mass pod $^{-1}$ in spring pea were higher in intercrops than in monocrop cultivation. The harvest index of spike, computed on the base of spike mass and seed mass spike ${ }^{-1}$ variate depends of plant species and crop system and was significantly different among small grain species grown in monocrops and intercrops. In the spring wheat, triticale and oat, the harvest index of spike was higher in wheat 
monocrop (71.9\%) than in wheat intercrop (70.8\%), in triticale monocrop $(65.3 \%)$ spike index was higher than in triticale intercrop (65.2\%), and in oat monocrop (89.2\%) spike index was higher than in oat/pea intercrop $(88.1 \%)$ while only in rye was higher in mixture with pea $(78.8 \%)$ was higher than in rye monocrops $(77.0 \%)$. In the same small grain species the harvest index of spike was different but not significantly different. In oat/pea intercrop obtained harvest index of spike was the significantly higher than spike index in intercrops wheat/pea, triticale/pea and then in wheat and triticale monocrop. The highest spike index was found in oat monocrop (89.2\%). The harvest index of pod was the least $72.9 \%$ in pea monocrop and the highest $79.4 \%$ in pea/oat intercrop. Harvest pod index was higher in spring pea grown in mixture with each small grains species genotypes than in pea's monocrops, but not significantly higher.

\section{Acknowledgement}

The research was funded by the Ministry of Education, Science and Technological Development of Republic of Serbia (TR 31007).

\section{References}

Aziz M., Mahmood A., Asif M., Ali A. (2015): Wheat-based intercropping: a review. The Journal of Animal \& Plant Sciences, 25 (4): 896-907.

BCRC- Beef Cattle Research Council. (2016): Cover Crops as Forage for Beef Cattle. /accessed 22. December, 2018/ http://www.beefresearch.ca/files/pdf/BCRC_Cover_Crops_Fact_Sheet.pdf

Branković G., Dodig D., Knežević D., Kandić V., Pavlov J. (2015): Heritability, genetic advance and correlations of plant height, spike length and productive tillering in bread wheat and durum wheat. Contemporary Agriculture, 64 (3-4): 150-157.

Chu M., Jagadamma S., Walker F.R., Eash N.S., Buschermohle M.J., Duncan L.A. (2017): Effect of multispecies cover crop mixture on soil properties and crop yield. Agricultural\& Environmental letter, 2:170030.

Davis C., Presley D., Farney J.K., Sassenrath G.F. (2015): Evaluating multispecies cover crops for forage production. Kansas Agricultural Experiment Station, Research Reports, 1(4).

Dimitrijević M., Petrović S., Kraljević-Balalić M., Panković L. (2006): Interakcija genotip/spoljna sredina mase zrna po biljci i indeksa klasa u Triticum sp. "Zbornik radova", Naučni institute za ratarstvo i povrtarstvo, Novi Sad, Sveska 42: 227-236.

Gill K.S., Omokanye A.T. (2018): Potential of spring barley, oat and triticale intercrops with field peas for forage production, nutrition quality and beef cattle diet. Journal of Agricultural Science, 10: 1-17.

Golijan J., Marković D. (2018): The benefits of organic production of medicinal and aromatic plants in intercropping system. Acta Agriculturae Serbica, 23 (45): 61-76.

Hadživuković S. (1991): Statistički metodi. Drugo izdanje. "Radivoj Ćirpanov", Novi Sad.

Hauggaard-Nielsen H., Jørnsgaard B., Kinane J., Jensen E.S. (2008): Grain legume-cereal intercropping: the practical application of diversity, competition and facilitation in arable and organic cropping systems. Renewable Agriculture Food Systems, 23: 3-12

Kadžiulienė Ž., Šarūnaitė L., Deveikytė I. (2011): Effect of pea and spring cereals intercropping on grain yield and crude protein content. Field and Vegetable Crops Research, 48: 183-188. 
Knezevic D., Radosavac A., Zelenika M. (2015): Variability of grain weight per spike of wheat grown in different ecological conditions. Acta Agriculturae Serbica, 20 (39): 85-95.

Knežević D., Maklenović V., Kolarić Lj., Mićanović D., Šekularac A., Knežević J. (2016): Variation and inheritance of nitrogen content in seed of wheat genotypes (Triticum aestivum L.). Genetika, 48 (2):579-586.

Knežević D., Paunović A., Kondić D., Radosavac A., Laze A., Kovačević V., Mićanović D. (2019a): Variability in seed germination of barley cultivars (Hordeum vulgare L.) grown under different nitrogen application rates. Acta Agriculturae Serbica, 24 (47): 61-69.

Knežević D., Paunović A., Zečević V., Urošević D., Kondić D., Mićanović D., Živić J., Madić M., Djurović V., Srdić S., Kovačević V. (2019b): Varijabilnost mase klasa sorti ozime pšenice (Triticum aestivum L.). XXIV Savetovanje o biotehnologiji sa međunarodnim učešćem. Čačak, 15-16. mart 2019. godine, Zbornik radova: 37-44.

Kondić D., Knežević D., Paunović A. (2012): Grain weight of genotypes of triticale ( $X$ Triticosecale Wittmack) in agroecological conditions of Banja Luka. Genetika, 44 (2): 419428.

Lauk R., Lauk E. (2008): Pea-oat intercrops are superior to pea-wheat and pea-barley intercrops. Acta Agriculturae Scandinavica. Section B: Plant and Soil Science, 58: 139-144

Lestingi A., Bovera F., DE Gorgio D., Ventrella D., Tateo A. (2010): Effects of tillage and nitrogen fertilisation on triticale grain yield, chemical composition and nutritive value. Jouranl of Science of Food and Agriculture, 90 (14): 2440-2446.

Madić M., Knežević D., Đurović D., Paunović A., Stevović V., Tomić D., Đekić V. (2019): Assesment of the correlation between grain yield and its components in spring barley and acid soil. Acta Agriculturae Serbica, 24 (47): 41-49.

Marković D. (2013): Crop diversification affects biological pest control. Agroknowledge, 14 (3): 449-459

Mikić A., Ćupina B., Mihajlović V., Krstić Đ., Đorđević V., Perić V., Srebrić M., Antanasović S., Marjanović-Jeromela A., Kobiljski B. (2012): Forage Legume Intercropping in Temperate Regions: Models and Ideotypes. In: Lichtfouse E. (eds) Sustainable Agriculture Reviews. Sustainable Agriculture Reviews, Springer, Dordrecht, 11: 161-182.

Nefir P., Tabără V. (2011): Effect on products from variety fertilization and triticale (Triticosecale Wittmack) in the experimental field from răcăşdia caras-severin country. Research Journal of Agricultural Science, 43 (4): 133-137.

Petrović S., Dimitrijević M., Kraljević-Balalić M., Mladenov N. (2002): Stabilnost indeksa klasa divergentnih genotipova pšenice. Zbornik radova, 36: 251-261, Naučni institut za ratarstvo i povrtarstvo, Novi Sad.

Sabolović V.(2014): Združena setva jednogodišnjih krmnih leguminoza u organskoj poljoprivredi. Master rad. Univerzitet u Novom Sadu, Poljoprivredni fakultet.

Simić A., Krga I., Simić M., Brankov M., Vučković S., Bijelić Z., Mandić V. (2018). Mogućnost suzbijanja korova združenim gajenjem jarog stočnog graška sa ovsem. Acta herbologica, 27 (2): 109-119.

Smith R.G., Gareau T.P., Mortensen D.A., Curran W.S., Barbercheck M.E. (2011): Assesing and visualizing agricultural management practices: A multivariable hands-on approach for education and extension. Weed Technology, 25: 680-687.

Smith R.G., Atwood L.W., Warren N.D. (2014): Increased productivity of a cover crop mixture is not associated with enhanced agroecosystem services. PLoS ONE. 9;e97351.

Stupar V., Paunović A., Madić M., Knežević, D. (2017): Influence of genotype and nitrogen nutrition on grain size variability in spring malting barley. Genetika, 49 (3):1095-1104. 
Tomm G.O., Foster R.K. (2001): Effect of intercropping wheat with forage legumes on wheat production and ground cover. Pesquisa Agropecuária Brasileira, 36 (3): 465-471.

Veličković M., Golijan J., Popović A. (2016): Biodiversity and organic agriculture. Acta Agriculturae Serbica, 21 (42): 123-134.

Xu C.H., Cai T., Wang L.Z., He R.M. (2015): Physiological basis for the differences of productive capacity among tillers in winter wheat. Journal of Integrative Agriculture, 14 (10):1958-1970.

Živanov D., Jevtić R., Tančić S., Vasiljević S., Maširević S. (2014): Control of winter forage pea diseases by pea-oat intercropping under field conditions. Pesticides and Phytomedicine, 29 (2):131-136. 


\title{
UTICAJ ZDRUŽENOG USEVA ŽITARICA + GRAŠAK NA INDEKS KLASA JARIH FORMI PŠENICE, TRITIKALE, OVSA I INDEKS MAHUNE GRAŠKA
}

\author{
Milosav Grčak ${ }^{1}$, Dragan Grčak ${ }^{1}$, Vesna Župunski ${ }^{2}$, Radivoje Jevtić ${ }^{2}$, \\ Mirjana Lalošević ${ }^{2}$, Adriana Radosavac ${ }^{3}$, Danijela Kondić ${ }^{4}$, Jelica Živić ${ }^{5}$, \\ Aleksandar Paunović ${ }^{6}$, Veselinka Zećević ${ }^{7}$, Danica Mićanović ${ }^{8}$, \\ Desimir Knežević ${ }^{1}$
}
${ }^{1}$ Univerzitet u Prištini, Poljoprivredni fakultet, Kosovska Mitrovica, Lešak, Kosovo i Metohija, Srbija
${ }^{2}$ Naučni institut za ratarstvo i povrtarstvo Novi Sad, Maksima Gorkog 30, 21000 Novi Sad, Srbija
${ }^{3}$ Univerzitet Privredna Akademija u Novom Sadu, Fakultet za primenjeni menadžment, ekonomiju i finansije, Beograd, Jevrejska 24, Beograd, Srbija
${ }^{4}$ Univerzitet u Banja Luci, Poljoprivredni fakultet Banja luka, Bulevar Vojvode Petra
Bojovića, 1A, 78000 Banjaluka, Republika Srpska, Bosna \& Hercegovina
${ }^{5}$ Visoka Poljoprivredno prehrambena škola u Prokuplju, Prokuplje, Srbija
${ }^{6}$ Univerzitet u Kragujevcu, Agronomski fakultet u Čačku, Cara Dušana 34, Čačak 32000, Srbija
${ }^{7}$ Univerzitet Megatrend, Belgrade, Facultet za Biofarming, Backa Topola, Serbia; ${ }^{8}$ Privredna komora Srbije, Resavska 15, Beograd, Srbija

\section{Rezime}

Prednosti i nedostaci združenih useva mogu se oceniti prema ispoljavanja komponenti prinosa na osnovu vrednosti produktivnih organa (klas, mahuna). Cilj ovog rad je izučavanje varijabilnosti žetvenog indeksa klasa pšenice, tritikalea, ovsa i žetvenog indeksa mahune kod graška gajenim u pojedinnačnim i združenim usevima. U istraživanja je uključen po jedan genotip jarih formi pšenice, tritikalea, ovsa i graška. Eksperiment je izveden na oglednom polju Rimski šančevi u Institutu za ratarstvo i povrtarstvo Novi Sad. Genotipovi strnih žita i graška su sejani na parcelicama $5 \mathrm{~m}^{2}$ u 4 ponavljanja u monokulturi i u združenoj setvii pšenica + grašak, tritikale + grašak i ovas+grašak. U vreme fiziološke zrelosti vršena je žetva biljke koje su korišćene za analizu osobina klasa i metlice kod strnih žita i osobina mahune kod graška. Za analize je korišćeno 40 biljaka (10 biljaka po ponavljanju) za svaki genotip iz pojedinačnih i združenih useva. Analizirane su osobine: masa klasa, masa semena po klasu, masa mahune i masa semena po mahuni. Na osnovu vrednosti ovih osobina izračunat je žetveni indeks klasa kod pšenice, tritikalea i ovsa kao i žetveni indeks mahune kod graška. Masa klasa je varirala izmedju $1.37 \mathrm{~g}$ kod tritikalea u združenom usevu sa graškom, do $2.23 \mathrm{~g}$ kod pšenice u združenom usevu sa graškom, a prosečna masa klasu za sve genotipove u obe varijante gajenja je iznosila $1.72 \mathrm{~g}$. Masa semena po klasu je 
varirala od 0.85 g kod pšenice u združenom usevu (pšenica+grašak) i u do 1.52 g kod ovsa u združenom usevu sa graškom, a prosečna masa semena po klasu za sve genotipove u obe varijante gajenja je iznosila 1.19 g. Žetveni indeks klasa je bio najmanji $62.5 \%$ kod tritikalea u pojedinačnm usevu a najveći kod ovsa $86.5 \%$ takodje u monokulturi. Vrednosri mase klasa i mase semena po klasu su bile različite u zavisnosti od vrste strnih žita i načina setve i gajenja useva. Masa klasa kod pšenice u združenom usevu sa graškom je bila veća nego kod pšenice u pojedinačnom usevu. Kod tritikalea i ovsa masa klasa je bila veća u pojedinačnm usevu nego u njihovom združenom usevu sa graškom. Masa semena po klasu kod pšenice, tritikalea i ovsa bila je veća u pojedinačnom usevu nego u njihovom združenom usevu sa graškom. Žetveni indeks klasa u monokulturi: kod pšenice $(71.9 \%)$ je bio veći nego u združenom usevu pšenica+grašak (70.8\%), kod tritikalea $(65.3 \%)$ je bio veći nego u združenom usevu (tritikale+grašak) i kod ovsa (89.2\%) je bio veći nego u združenom usevu sa graškom $(88.1 \%)$.

Kod graška, masa semena po mahuni je varirala od $0.33 \mathrm{~g}$ u pojedinačnom usevu do $0.57 \mathrm{~g} \mathrm{u}$ združenoj setvi sa tritikaleom, a prosečna nasa semena po mahuni u oba sistema gajenja bila 0.46 g. Masa mahune je bila najmanja kod graška u pojedinačnom usevu $0.45 \mathrm{~g}$ a najveća $0.72 \mathrm{~g} \mathrm{u}$ združenom usevu sa tritikaleom, a prosečna vrednost mahune u svim varijantama gajenja je iznosila $0.59 \mathrm{~g}$. Žetveni indeks mahune je varirao izmedju $72.9 \%$ u pojedinačnom usevu graška i 79.4\% u usevu združene setve graška i ovsa. Vrednosti za masu mahune, masu semena po mahuni i žetveni indeks mahune su bile veće u združenim usevima graška sa pšenicom, tritikaleom i ovsom ali nizi bile značajno različite. Dobijeni rezultata, ukazuju da združena setva graška i strnih žita ima pozitivan efekat na ispoljavanje većih vrednosti osobina klasa i osobina mahune.

Ključne reči: žetveni indeks klasa, ŽI mahune, strna žita, grašak, združena setva. 